\section{Global Fund toughens stance against corruption}

\author{
Richard Feachem of the Global Fund to Fight \\ AIDS, Tuberculosis, and Malaria tells Lynn \\ Eaton how the fund sees the enforcement of \\ transparency and accountability as a vital step in \\ ensuring results
}

The recent decision by the Global Fund to Fight AIDS, Tuberculosis, and Malaria to suspend grants to Uganda on the grounds that the funds were misappropriated $(B M J$ 2005;331:475) feeds the common perception that corruption is more rife in African countries than elsewhere around the world.

Whether corruption is any worse in an African country than, say, in India or El Salvador, is open to debate. But how do aid agencies ensure that their funds are used for the purposes for which they are intended? And, from a medical viewpoint, what are the ramifications for public health if a funding organisation takes the difficult decision to suspend a grant?

Dr Richard Feachem, executive director of the fund, fully

accepts the difficulty of what he described as the "life and death" decision they had to make over Uganda. The grants were worth a total of $\$ 201 \mathrm{~m} \quad(113 \mathrm{~m}$; $€ 167 \mathrm{~m}$ ) over two years, of which $\$ 45.4 \mathrm{~m}$ had already been disbursed.

Speaking at the recent replenishment meeting of the fund in London, he and Hilary Benn, UK secretary of state for international development, told journalists that although it was a hard decision to take, the action would only reinforce trust in the fund.

Dr Feachem also acknowledged that if suspending funding led to the withdrawal of treatments not only would it hasten the death of people who had been receiving the treatments

\begin{tabular}{|c|c|c|}
\hline $\begin{array}{l}\text { Perception of corrupti } \\
\text { overall ranking and sc }\end{array}$ & $\begin{array}{l}\text { various } \\
10=\text { no }\end{array}$ & $\begin{array}{l}\text { ntrie } \\
\text { uptio }\end{array}$ \\
\hline & Ranking & Score \\
\hline Finland & 1 & 9.7 \\
\hline UK & 11 & 8.6 \\
\hline US & 17 & 7.5 \\
\hline Botswana & 31 & 6.0 \\
\hline South Africa & 44 & 4.6 \\
\hline China & 71 & 3.4 \\
\hline Gambia & 90 & 2.8 \\
\hline India & 90 & 2.8 \\
\hline Eritrea & 102 & 2.6 \\
\hline Uganda & 102 & 2.6 \\
\hline Zambia & 102 & 2.6 \\
\hline Yemen & 112 & 2.2 \\
\hline Sudan & 122 & 2.2 \\
\hline Kenya & 129 & 2.1 \\
\hline Angola & 133 & 2.0 \\
\hline Democratic Republic of Congo & 133 & 2.0 \\
\hline Chad & 142 & 1.7 \\
\hline Nigeria & 144 & 1.6 \\
\hline Bangladesh & 145 (worst) & 1.5 \\
\hline Haiti & 145 (worst) & 1.5 \\
\hline
\end{tabular}

Source: Transparency International (www.tranparency.org), a Berlin based organisation that monitors perceptions of corruption worldwide. The people surveyed included business people and country analysts. The table above is an extract from the annual survey.

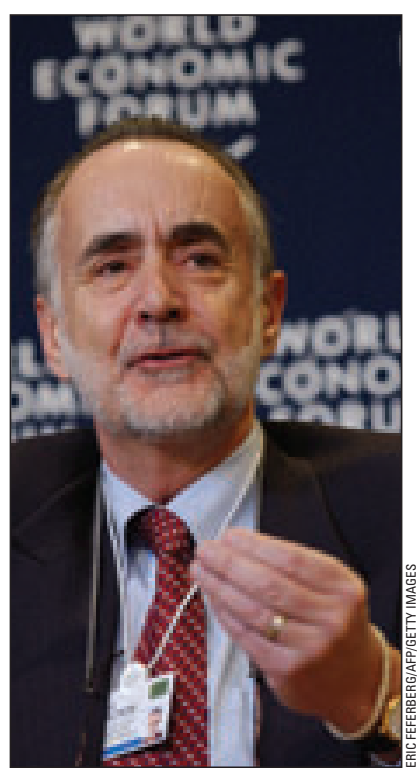

Dr Richard Feachem argues that corruption is a global problem

but it could also increase the resistance of the disease to drug treatments in future.

That's something that really concerns the Ugandan Leonard Okello, who is international head of the HIV and AIDS programme run by the charity Action Aid. The charity's projects in Uganda received 100 million Ugandan shillings (£30 500; \$54000; €45000) from the fund.

"When we lose it, that means a lot for us," says Mr Okello. "The big challenge for us is the effect on treatment levels. My biggest worry is continuity of treatment."

Nevertheless he believes the fund made the right decision to suspend funding.

"When something goes wrong, the recipients of the money should be made to know somebody is going to question it," he said. "African government ministers must be held accountable by the citizens of Africa and by those who gave the money."

Until now that has not always happened, he said. "Those who give the money... are sometimes a bit naive."

The UK Department for International Development, for example, spent more than $£ 345$ m million on work on HIV and AIDS in developing countries in 2003-4. Yet it was recently criticised by the charity Action Aid for failing to track adequately how its grants were spent.

$\mathrm{Mr}$ Okello believes more transparency is the answer, something Dr Feachem agrees with. But Dr Feachem argues that corruption can happen anywhere, not just in countries in Africa.

"It happens in the UK and in the US," he said. "It is a global problem. But there are clearly some settings that are symptomatically corrupt. They tend to be poor countries, but not necessarily African ones. They are ones where there is no framework of good government, where there is no rule of law, where accounting procedures are just not in place.

"All organisations involved in development finance, including the World Bank, face the constant risk of possible misappropriation of funds and of corruption. That's a fact of life in development finance. The key is to minimise the risk-to have in place oversight systems and to identify problems before they occur."

The Global Fund to Fight AIDS, Tuberculosis, and Malaria, he said, was an "extremely transparent" organisation. All the money it receives or spends is detailed on its website, which he described as "second to none among development agencies."

"The simple fact that everything is on the website is a risk reduction strategy in relation to corruption. It allows everybody to watch what everybody is doing. That includes allowing non-governmental organisations who are distrustful of government to watch government, as well as vice versa," Dr Feachem said.

Another safety mechanism is that the fund agrees to finance schemes only on the basis of actual results. "That is immediately a break on corruption," said Dr Feachem. He argues that if the money has not been spent appropriately then there won't be any results to show for it, and the project will lose out in the next funding round.

The fund also retains the services of local agents who are responsible for administering the funds and ensuring they are spent appropriately. In most countries the agents will be local outposts of international accountancy firms such as PricewaterhouseCoopers or KPMG.

Lynn Eaton London

See www.theglobalfund.org 